\title{
Pathogenicity and virulence of coagulase negative staphylococci in relation to adherence, hydrophobicity, and toxin production in vitro
}

\author{
C Molnàr, Z Hevessy, F Rozgonyi, C G Gemmell
}

\begin{abstract}
Aims-To study the pathogenicity and virulence characteristics of Staphylococcus epidermidis, Staphylococcus haemolyticus, and Staphylococcus sapro-phyticus.

Methods-BALB/c mice were challenged intraperitoneally with graded doses of three strains belonging to each species. $\mathbf{L D}_{50 \mathrm{~s}}$ were measured for each strain. Haemolysin ( $\alpha$ - and $\delta-$ ) and enzyme (DNAase, lipase, and esterase) production in vitro were measured qualitatively and quantitatively. Adhesion to plastic was measured and related to cell surface hydrophobicity among the strains.

Results-S saprophyticus proved the most virulent $\left(L_{50}=2.7-2.9 \times 10^{7} \mathrm{cfu} / \mathrm{g}\right.$ body weight) while $S$ epidermidis was the least virulent $\left(\mathrm{LD}_{50}=6-8 \times 10^{7} \mathrm{cfu} / \mathrm{g}\right.$ body weight). An enlarged spleen was the most common macroscopic pathological feature. Kidney, liver, and more rarely peritoneal abscesses were also seen in the infected animals. No direct correlation was found between adherence in vitro, cell surface hydrophobicity, or toxin/enzyme biosynthesis and virulence in mice.

Conclusion-The results show that coagulase negative staphylococci are pathogenic in $B A L B / c$ mice. It is clear that these bacteria can cause invasive disease. However, the in vitro characteristics of coagulase negative staphylococci are not related to the pathogenicity of the organisms in mice.
\end{abstract}

Department of Clinical Chemistry

Z Hevessy

Department of

Microbiology, Medical

University of

Debrecen, Debrecen,

Hungary

C Molnàr

Z Hevessy

F Rozgonyi

Department of

Bacteriology, Royal

Infirmary, University

of Glasgow, Glasgow

G4 OSF, Scotland

C G Gemmell

Correspondence to:

Dr C G Gemmell

Accepted for publication

9 February 1994 tract, cerebrospinal fluid shunts and prostheses; in septicaemias in premature neonates tonitis in patients receiving continuous ambulatory peritoneal dialysis; and in postoperative endocarditis. ${ }^{9}$ Szabo et al found that these organisms are the second most common pathogens in infected burn lesions. (Szabò J, et al. Abstract presented at the 16th International Congress of Chemotherapy, Jerusalem, 1989).

Staphylococcus epidermidis proved the most common cause of the infections mentioned above $^{236710}$ except in those of the urinary tract where Staphylococcus saprophyticus dominates. ${ }^{11}$ Staphylococcus haemolyticus seems to rank third in order of frequency. ${ }^{12}$

The study of the pathogenesis of coagulase negative staphylococci has shown that several extracellular metabolites are produced by these micro-organisms. ${ }^{13-15}$ There are also many substances on the surfaces of the bacteria involved in pathogenicity, such as haemagglutinin, capsule, slime, fibronectin binding proteins and collagen binding proteins. ${ }^{16-23}$

The aim of the present study was to investigate the virulence of the three most common coagulase negative Staphylococcus species in experimental infections of mice on the basis of lethality, splenomegaly, and the prevalence of tissue abscesses in relation to hydrophobicity, adherence, and toxin production.

\section{Methods}

BACTERIAL STRAINS

$S$ epidermidis (three strains) were isolated from blood or wound discharge from patients with left atrioventricular stenosis after valve implantation, severe aplastic anaemia, and pneumonia. $S$ haemolyticus (three strains) were isolated from the skin of a burn patient, from the blood of a case of septicaemia, and from the urine of a patient with prostatitis. The two clinical $S$ saprophyticus strains were from the urine of a patient with chronic pyelonephritis and from the wound infection of a burn patient, respectively. The third strain was the reference strain $S$ saprophyticus HNCMB 110008. The strains were identified according to a combined taxonomic scheme derived from Kloos and Schleifer ${ }^{24}$ and Akatov et al. ${ }^{25}$ The strains were stored in trypticase-soy broth containing $25 \%$ glycerol at $-20^{\circ} \mathrm{C}$ and subcultured at six monthly intervals. Full details are presented in table 1 .

\section{ADHERENCE}

Adherent growth was examined using the 
Table 1 Clinical data of coagulase negative staphylococcal strains

\begin{tabular}{|c|c|c|c|c|c|}
\hline Staphylococcus sp & Strain No & Patient & Department & Diagnosis & Specimen \\
\hline $\begin{array}{l}S \text { epidermidis } \\
\text { S epidermidis } \\
S \text { epidermidis }\end{array}$ & $\begin{array}{l}5905 \\
8602 \\
8915\end{array}$ & $\begin{array}{l}\text { Male } \\
\text { Male } \\
\text { Female }\end{array}$ & $\begin{array}{l}\text { Paediatrics } \\
\text { Paediatrics } \\
\text { Cardiac surgery }\end{array}$ & $\begin{array}{l}\text { Pneumonia } \\
\text { Aplastic anaemia } \\
\text { Left atrioventricular } \\
\text { stenosis after } \\
\text { valve implantation }\end{array}$ & $\begin{array}{l}\text { Blood } \\
\text { Blood } \\
\text { Wound discharge }\end{array}$ \\
\hline $\begin{array}{l}S \text { haemolyticus } \\
\text { S haemolyticus } \\
\text { S haemolyticus } \\
\text { S saprophyticus }\end{array}$ & $\begin{array}{l}367 \\
9381 \\
11684 \\
3876\end{array}$ & $\begin{array}{l}\text { Male } \\
\text { Female } \\
\text { Female } \\
\text { Female }\end{array}$ & \multirow{2}{*}{$\begin{array}{l}\text { Urology } \\
\text { Dermatology } \\
\text { Paediatrics } \\
\text { Internal medicine } \\
\text { Nephrology } \\
\text { Dermatology }\end{array}$} & $\begin{array}{l}\text { Prostatitis } \\
\text { Burn } \\
\text { Sepsis } \\
\text { Chronic } \\
\quad \text { pyelonephritis }\end{array}$ & $\begin{array}{l}\text { Urine } \\
\text { Wound swab } \\
\text { Blood } \\
\text { Urine }\end{array}$ \\
\hline $\begin{array}{l}S \text { saprophyticus } \\
S \text { saprophyticus }\end{array}$ & $\begin{array}{l}4922 \\
110008 \mathrm{HI}\end{array}$ & $\begin{array}{l}\text { Male } \\
\text { B referen }\end{array}$ & & Burn & Wound swab \\
\hline
\end{tabular}

tube adherence method described by Christensen et al. ${ }^{16}$ Cultivation of each of the strains was performed in both trypticase-soy broth containing $1 \%$ glucose (TSB, Difco Laboratories Detroit, Michigan, USA) and in $1 \%$ glucose-meat broth prepared in our laboratory. Each test was repeated five times.

\section{HYDROPHOBIC INTERACTION CHROMATOGRAPHY (HIC)}

HIC was performed on octyl-sepharose gel (Pharmacia, Uppsala, Sweden). Three $1 \mathrm{~cm}$ columns of gel in Pasteur pipettes were equilibrated with $4.5 \mathrm{ml}$ of $0.02 \mathrm{M}$ sodium phosphate buffer ( $\mathrm{pH} \mathrm{6.8)}$ and $0.1 \mathrm{M}$ and $0.5 \mathrm{M}$ ammonium sulphate solution in $0.02 \mathrm{M}$ sodium phosphate buffer ( $\mathrm{pH}$ 6.8) for each strain. A standardised suspension of bacteria $(100 \mu \mathrm{l})$ harvested from modified Columbia Agar Base (Oxoid, Basingstoke, Hants, England) supplemented with 5\% defibrinated bovine blood was applied to the gel columns.

The same suspension of bacteria was added to $3 \mathrm{ml}$ buffer as a control. Immediately after adding the bacterial suspension to the gel, non-adsorbed bacteria were eluted from the gel with $3 \mathrm{ml}$ of buffer. The absorbance of eluates were measured at $540 \mathrm{~nm}$, and the percentage of bacterial binding to the gel was calculated. The control was considered as $0 \%$ binding; thus lower absorbance values meant positive binding.

\section{IMPROVED SALT AGGREGATION TEST (ISAT)}

This was performed by mixing one drop of standardised bacterial suspension with one drop of ammonium sulphate solution $(0.2 \mathrm{M}$ to $3 \mathrm{M}$ ) coloured with methylene-blue on white hydrophobic paper. The ISAT value was taken as the lowest molarity of ammonium sulphate at which aggregation occurred within five minutes. If aggregation occurred only at molarities of or above $1.5 \mathrm{M}$, bacteria were regarded as hydrophilic. ${ }^{17}$

The haemolytic activity of the strains was examined by growth for 24 hours on layered nutrient agar plates supplemented with defibrinated human, rabbit, horse and sheep blood, respectively.

\section{TOXIN PRODUCTION IN VITRO}

Each strain was grown for 18 hours by shaking in either brain-heart infusion broth (for lipase, esterase, and DNAase), yeast dialysate medium $^{26}$ (for $a$-haemolysin), or Gladstone and van Heyningen ${ }^{27}$ medium (for $\delta$ - haemolysin). Then cultures were centrifuged to remove the bacteria and sodium thiomersalate ( 1 in 1000 of a $1 \%$ solution) was added as a preservative to the supernatant fluids.

\section{TOXIN ASSAYS}

a-haemolysin

Serial doubling dilutions of toxin $(0.2 \mathrm{ml})$ were made in saline and equal volumes of $2 \%$ $(v / v)$ fresh rabbit erythrocyte suspension added to wells of a microtitre plate. The plate was incubated at $37^{\circ} \mathrm{C}$ for one hour.

Haemolysin titre was taken as the reciprocal of the highest dilution of toxin just causing $50 \%$ haemolysis of the erythrocytes.

\section{$\delta$-haemolysin}

Serial doubling dilutions of toxin $(0.2 \mathrm{ml})$ were made in saline and equal volumes of $2 \%$ (v/v) fresh human erythrocyte suspension added to wells of a microtitre plate. The plate was incubated at $37^{\circ} \mathrm{C}$ for one hour. The haemolysin titre was taken as the reciprocal of the highest dilution of toxin just causing $50 \%$ haemolysis of the erythrocytes.

\section{DNAase, lipase, and esterase}

Serial dilutions of toxin $(0.1 \mathrm{ml})$ in saline were added to wells cut in agar containing either $1 \%$ DNA, $1 \%$ glycerol tributyrate, or $1 \%$ Tween 80 as enzyme substrate. The presence or absence of zones of clearing (lipase), precipitation (esterase), or clearing after addition of hydrochloric acid (DNAase) were taken as an indication of positive enzyme activity.

PREPARATION OF BACTERIAL SUSPENSION FOR USE IN THE INFECTION MODEL

Strains were precultured on blood agar at $37^{\circ} \mathrm{C}$ for 24 hours, followed by subculture for a further 24 hours at $37^{\circ} \mathrm{C}$ on modified Columbia Base Agar plates (Difco Laboratories, Detroit, Michigan, USA, or Oxoid Ltd, Basingstoke, Hants, England) containing $5 \%$ bovine blood (Phylaxia, Budapest, Hungary) and $2 \%$ sodium chloride. Bacteria were collected from the plates with sterile cotton wool swabs and suspended in a physiological dextran solution (Fluidex 40, Polfa, Warsaw, Poland) as microcarrier. ${ }^{28}$ Basic bacterial suspensions were spectrophotometrically standardised from which serial dilutions of known bacterial counts were prepared. At the same time a calibration curve was made to determine the number of colony forming units (cfu) corresponding to different bacterial densities. 
Table 2 Adherence and hydrophobicity of strains of different species of coagulase negative staphylococci

\begin{tabular}{|c|c|c|c|c|}
\hline \multirow[b]{2}{*}{ Test strains } & \multirow[b]{2}{*}{$\begin{array}{l}\text { Adherent } \\
\text { growth on } \\
\text { plastic }\end{array}$} & \multicolumn{2}{|c|}{ Mean (SEM) HIC value ${ }^{*}$ : } & \multirow[b]{2}{*}{$\begin{array}{l}\text { ISAT } \\
\text { valuet }\end{array}$} \\
\hline & & $\begin{array}{l}0.02 \mathrm{M} \\
\text { phosphate } \\
\text { buffer }\end{array}$ & $\begin{array}{l}0 \cdot 1 \mathrm{M} \\
\text { ammonium } \\
\text { sulphate }\end{array}$ & \\
\hline \multicolumn{5}{|l|}{$S$ epidermidis } \\
\hline $\begin{array}{l}8602 \\
8915 \\
5905\end{array}$ & $\begin{array}{l}\text { No } \\
\text { Yes } \\
\text { No }\end{array}$ & $\begin{array}{l}43.5(0.58) \\
23.0(3.37) \\
25.0(4.62)\end{array}$ & $\begin{array}{l}75.5(11 \cdot 0) \\
47.5(1.9) \\
56.5(2.9)\end{array}$ & $\begin{array}{l}1.45(0.06) \\
1.50(0) \\
1.45(0.06)\end{array}$ \\
\hline \multicolumn{5}{|l|}{$S$ haemolyticus } \\
\hline 367 & No & $94 \cdot 7(5 \cdot 3)$ & $95 \cdot 5(8 \cdot 1)$ & $0.50(0)$ \\
\hline 9381 & No & $48 \cdot 5(6 \cdot 4)$ & $74.0(0)$ & $0.35(0.17)$ \\
\hline 11684 & No & $53.0(0)$ & $95 \cdot 5(1 \cdot 7)$ & $1.45(0.06)$ \\
\hline \multicolumn{5}{|l|}{$S$ saprophyticus } \\
\hline $\begin{array}{l}3876 \\
4922\end{array}$ & No & $\begin{array}{l}24 \cdot 0(1 \cdot 2) \\
34 \cdot 5(1 \cdot 7)\end{array}$ & $32 \cdot 0(5 \cdot 8)$ & $1 \cdot 05(0 \cdot 06)$ \\
\hline $\begin{array}{r}4922 \\
110008\end{array}$ & Yes & $8 \cdot 0(2 \cdot 3)$ & $18.5(0.6)$ & $1.67(0 \cdot 26)$ \\
\hline
\end{tabular}

*Expressed as per cent of bacteria adsorbed on to octyl-sepharose gel relative to a suspension of bacteria in buffer.

†The lowest molarity of ammonium sulphate at which aggregation occurred.

MOUSE INFECTION MODEL

Four month old, inbred BALB/c mice were grouped according to sex and weight. The random selection of mice in this population followed a natural distribution. Four groups of male mice and four groups of female mice were challenged with graded doses of each bacterial strain calculated on the basis of body weight. Mice were injected intraperitoneally with $0.3-0.5 \mathrm{ml}$ (depending on their weight) of the proper bacterial suspension warmed to body temperature. The same volume of Fluidex 40 was injected into control mice. The mice were fed freely and their behaviour was observed for 10 days after infection.

Mice dying within two days of challenge were dissected immediately; those surviving for 10 days were sacrificed and examined for changes in the peritoneum, liver, spleen and kidneys. Spleens of non-infected mice measured 17-20 mm. In infected mice, spleens measuring $21-25 \mathrm{~mm}$ were regarded as displaying moderate splenomegaly, and spleens above $25 \mathrm{~mm}$ as displaying advanced splenomegaly.

\section{Results}

ADHERENCE AND HYDROPHOBICITY/

HYDROPHILICITY

Only one of the three $S$ epidermidis strains and one of the three $S$ saprophyticus strains adhered well to plastic, while two of each

Table 3 Haemolysin production in vitro by strains of different Staphylococcus species

\begin{tabular}{|c|c|c|}
\hline \multirow{2}{*}{$\begin{array}{l}\text { Staphylococcus } \\
\text { strain }\end{array}$} & \multicolumn{2}{|l|}{ Titre of } \\
\hline & $\alpha$-haemolysin & $\delta$-haemolysin \\
\hline \multicolumn{3}{|l|}{$S$ epidermidis } \\
\hline $\begin{array}{l}8602 \\
8915 \\
5905\end{array}$ & $\begin{array}{l}1 / 16 \\
1 / 4 \\
1 / 2\end{array}$ & $\begin{array}{l}1 / 8 \\
1 / 2\end{array}$ \\
\hline \multicolumn{3}{|l|}{$S$ haemolyticus } \\
\hline $\begin{array}{r}367 \\
9381\end{array}$ & $\begin{array}{l}1 / 4 \\
1 / 4\end{array}$ & \\
\hline 11684 & $1 / 8$ & $1 / 8$ \\
\hline \multicolumn{3}{|l|}{$S$ saprophyticus } \\
\hline 3876 & $1 / 4$ & \\
\hline HNCMB 110008 & $1 / 2$ & \\
\hline 4922 & $1 / 8$ & $1 / 2$ \\
\hline
\end{tabular}

species failed to adhere. None of the $S$ haemolyticus strains was adherent. All three $S$ epidermidis strains proved hydrophilic in both tests. Two of the three $S$ haemolyticus strains were hydrophobic in both assays, while strain $S$ haemolyticus 11684 was hydrophobic by HIC and hydrophilic by ISAT. Strain 3876 was fully hydrophilic by HIC but moderately hydrophobic by ISAT; HNCMB 110008 was hydrophilic in both tests; strain 4922 was hydrophobic in both tests. As a whole, no association was found between adherence and hydrophobicity or hydrophilicity of the strains (table 2).

\section{TOXIN PRODUCTION}

The strains differed considerably in the yield of haemolysin in culture supernatant fluids (table 3). Slight DNAase activity was shown only by $S$ saprophyticus strain 110008, and slight lipase activity was detected in $S$ epidermidis strain 8602; esterase was produced by $S$ haemolyticus strain 11684, and by $S$ saprophyticus strains 3876 and 4922 (data not shown).

\section{PATHOGENICITY AND LETHALITY TO MICE}

The same challenge dose of bacteria killed more male mice than females. All three strains of each Staphylococcus species were pathogenic for mice but there was a pronounced difference between the lethal doses of the different bacterial species: $S$ saprophyticus proved the most virulent $\left(\mathrm{LD}_{50}=2.7-2.9 \times 10^{7} \mathrm{cfu} / \mathrm{g}\right.$ body weight); $S$ haemolyticus was somewhat less virulent $\left(\mathrm{LD}_{50}=2.9-3.8 \times 10^{7} \mathrm{cfu} / \mathrm{g}\right.$ body weight); and the least virulent was $S$ epidermidis $\left(\mathrm{LD}_{50}=6-8 \times 10^{7} \mathrm{cfu} / \mathrm{g}\right.$ body weight). These differences in lethality were significant $(p<0.0001)$. However, within each species the virulence of the various strains differed. For this reason results are shown as dose ranges instead of doses characterised by exact numbers.

Each coagulase negative Staphylococcus species caused visible organ damage; the most common macroscopic lesion was splenomegaly (verified by histological examination) (fig 1) in mice sacrificed on the 10th day after infection; liver, peritoneal, or kidney abscesses were also sometimes observed.

Table 4 shows that strains of $S$ epidermidis caused splenomegaly most frequently and those of $S$ haemolyticus rarely. By studying the prevalence of splenomegaly according to the species injected, more than half $(52.4 \%)$ of all the cases of splenomegaly were found in the group infected with $S$ epidermidis (fig 2), although mice challenged with $S$ epidermidis made up only 79 of the 245 survivors. The different coagulase negative species, therefore, cause splenomegaly at significantly different frequencies $(p<0.001)$. On the other hand, the numbers of cases of splenomegaly were directly proportional to $\mathrm{LD}_{50}(\mathrm{p}<0.001)$ of each of the three species (data not shown).

Liver abscesses were found in 28 of the 245 surviving mice: $28 \%$ of them had been challenged with $S$ saprophyticus, $72 \%$ with $S$ epidermidis. No liver abscesses occurred after the injection of $S$ haemolyticus indicating that the 


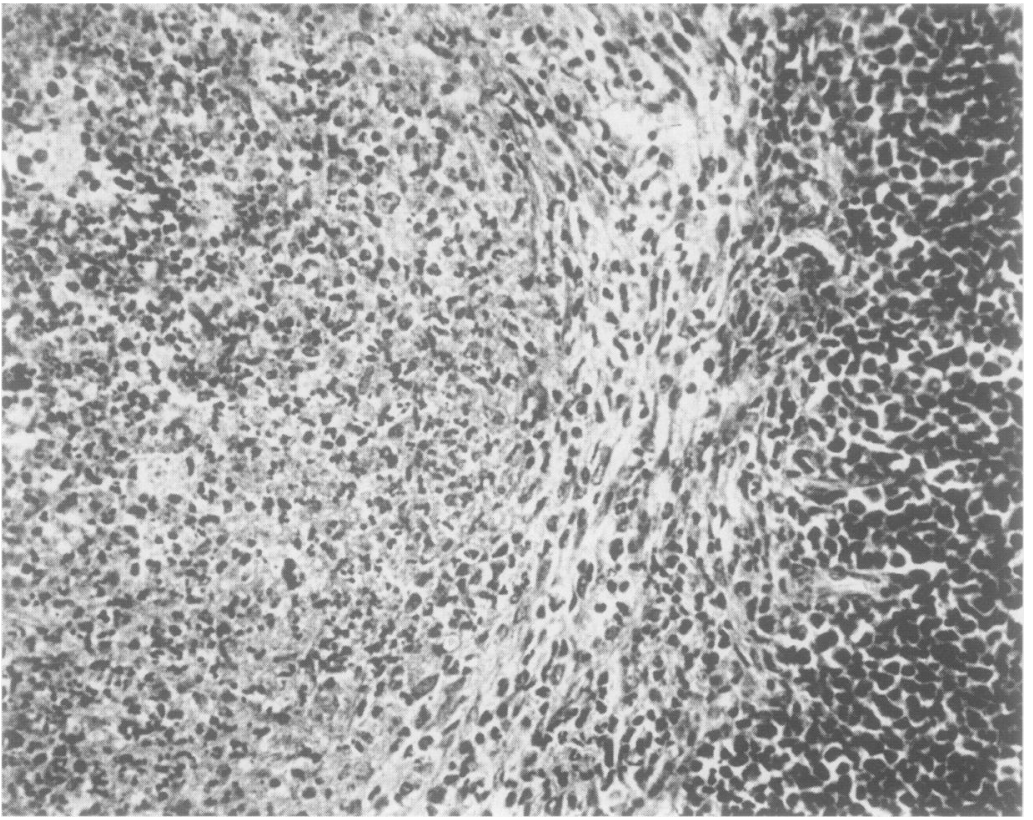

Figure 1 Histological appearance of splenic abscess in mouse infected with coagulase negative staphylococci (haematoxylin and eosin).
Normal sized spleens $(n=113)$

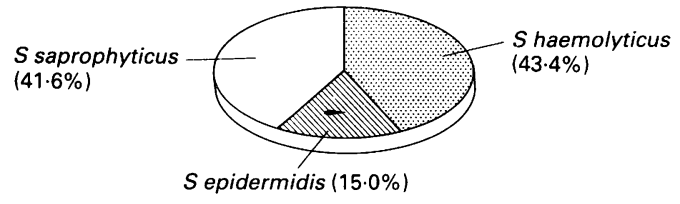

Moderate splenomegaly $(n=90)$

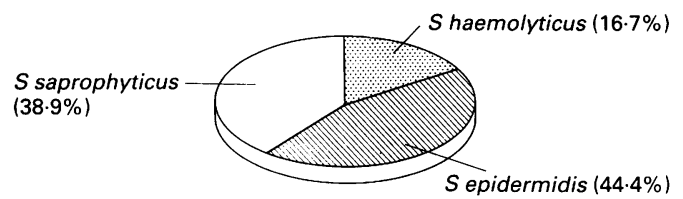

Advanced splenomegaly $(n=42)$

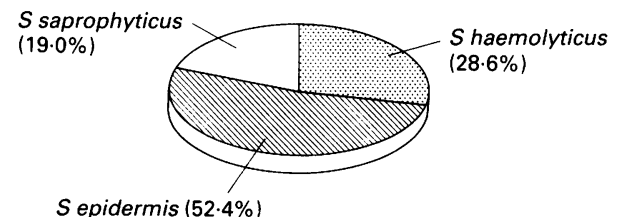

Figure 2 Incidence of splenomegaly in relation to intraperitoneal infection of mice with different species of coagulase negative staphylococci.

intraperitoneally. ${ }^{2830}$ According to the observations of Ichiman and Yoshida, ${ }^{31}$ only 13 of 300 randomly chosen freshly isolated clinical strains of $S$ epidermidis were virulent for mice. Namavar $e t a l^{2}$ found that the $\mathrm{LD}_{50}$ of different biotypes of $S$ epidermidis ranged from $7 \cdot 1-7 \cdot 8$ $\times 10^{5}$ following intracerebral challenge of newborn mice. Christensen et $a l^{20}$ showed that mice were not infected by $S$ epidermidis without the use of foreign body implants. Baddour et $\mathrm{al}^{33}$ found that with an inoculum of $1 \times 10^{7} \mathrm{cfu}$ endocarditis was established in all of 77 rats injected with $S$ epidermidis but in only five $(12.5 \%)$ of 40 animals injected with Staphylococcus hominis. Jonsson et al ${ }^{34}$ showed that $S$ epidermidis and $S$ haemolyticus were not pathogenic in a mouse mastitis model, even when a large dose of inoculum was used, while in the neonatal mouse weight gain test four of nine coagulase negative staphylococcus strains caused weight loss suggesting some virulence.

In our present study each of the clinical strains of $S$ epidermidis, $S$ haemolyticus, and $S$ saprophyticus has been shown to be pathogenic for mice according to the criteria of Ichiman and Yoshida. ${ }^{31}$ The degree of virulence is similar to that of methicillin resistant strains of Staphylococcus aureus ${ }^{27} ; S$ saprophyticus is the most virulent, $S$ haemolyticus somewhat less so, and $S$ epidermidis is the least virulent. All strains of the three Staphylococcus species are invasive in mice with an intact immune system after intraperitoneal challenge. Considerable differences were seen in mouse virulence among the strains of the same species, which was similar to the findings of Namavar et al. ${ }^{32}$

Our results show the complexity of coagulase negative staphylococcal infections and indicate the present insufficiency of in vitro

tests as predictors of pathogenicity of a given after infection with different species of coagulase negative staphylococci

\begin{tabular}{llll} 
Spleen size & S epidermidis & S haemolyticus & S saprophyticus \\
\hline $\begin{array}{llll}\text { Normal }(<20 \mathrm{~mm}) \\
\begin{array}{c}\text { Moderate splenomegaly } \\
(20-25 \mathrm{~mm})\end{array}\end{array}$ & $17(21 \cdot 5)$ & $49(64 \cdot 5)$ & $47(51 \cdot 2)$ \\
$\begin{array}{c}\text { Advanced splenomegaly } \\
(>25 \mathrm{~mm})\end{array}$ & $40(50 \cdot 6)$ & $15(19 \cdot 7)$ & $35(38 \cdot 9)$ \\
Splenomegaly (total) & $22(27 \cdot 8)$ & $12(15 \cdot 8)$ & $8(8 \cdot 9)$ \\
\hline
\end{tabular}


coagulase negative staphylococcus strain or species. The lack of correlation between in vitro adherence and hydrophobicity suggests that different surface components determine these two properties. On the other hand, the presence or absence of these characters in vitro gives no information about the severity and outcome of infection, because no association was found between in vitro adherence, hydrophobicity or hydrophilicity, and lethality. Toxin production in vitro by coagulase negative staphylococcus strains may reflect the severity of the infection, as one strain of $S$ epidermidis which elaborated the highest titres of both haemolysins (compare table 3 and fig 2) also had the lowest $L D_{50}$. The role of haemolytic toxins in the pathogenesis of coagulase negative staphylococcal infections is far from clear because it is not known whether haemolysin production occurs in vivo, and how the toxins might interact with other bacterial and host factors. ${ }^{13}$

Similarly, Lambe et $a l,{ }^{35}$ in a subcutaneous abscess model initiated by implantation of catheter segments coated with each of five species of coagulase negative staphylococci, were unable to relate abscess formation to the presence of glycocalyx or the production of various toxins in vitro. All $S$ haemolyticus strains produced haemolysins in vitro (table 3 ), suggesting that haemolysin may contribute to the high virulence of this species. In contrast, the higher virulence of $S$ saprophyticus is impossible to interpret on the basis of our in vitro data. However, Beuth and coworkers ${ }^{18}$ have shown that $S$ saprophyticus is unique among coagulase negative staphylococci because it possesses at least three types of specific surface lectin. The presence of high amounts of these lectins on the surface of the cocci, when injected into the peritoneal cavity, may contribute to their virulence by altering host macrophage function. ${ }^{19}$

Experimental $S$ epidermidis infection is characterised by a low $\mathrm{LD}_{50}$ and a significantly high incidence of splenomegaly in the survivors. This is the first report, as far as is known, to show the spleen as a target organ for coagulase negative staphylococci. Splenomegaly is usually caused by lymphoproliferation and may be associated with the ability of staphylococcal extracellular slime to stimulate production of immunologically competent cells, ${ }^{36}$ but doubts about the purity of the material used in these experiments and difficulties in distinguishing some surface components of coagulase negative staphylococci ${ }^{37}$ may render this mechanism open to doubt. The strains used in the present study, although shown to have variable adherence to plastic, were not examined for the presence of slime. As yet we cannot ascribe any particular property to the coagulase negative staphylococci which could be responsible for the features seen in our mouse model of infection.

The skillful technical assistance of Mrs Erzsèbet Papp-Falusi, Jolán Varga, Katalin Rozgonyi-Szitha, Mr József Bánk and the late Mr László Cserna is appreciated.

This work was supported by the National Scientific Research Fund of Hungary, grant No. OTKA 712 (1986-90) and OTKA 1470 (1991-94).
1 Davies AJ. Coagulase negative staphylococcal infections. $B M \mathcal{F}$ 1985;290:1230-1.

2 Hansen BG. Coagulase-negative staphylococci and micrococci in clinical microbiology. Dan Med Bull 1987;34: 96-114.

3 Lanzilli G, Spanò C. Bacterial contamination of intravenous catheters and other plastic devices. Infection 1987;15:42-3.

4 Pfaller MA, Herwaldt LA. Laboratory, clinical, and epidemiological aspects of coagulase-negative staphylococci. Clin Microbiol Rev 1988;1:281-99.

5 Sugarman B, Young EJ. Infections associated with prosthetic devices. Boca Raton, Florida: CRC Press, 1984

6 Fidalgo S, Vázquez F, Mendoza MC, Pérez F, Méndez FJ. Bacteremia due to Staphylococcus epidermidis: microbiologic, epidemiologic, clinical, and prognostic features. Rev Infect Dis 1990;12:520-7.

7 Righter J. Septicemia due to coagulase-negative Staphylococcus in a community hospital. Can Med Assoc F 1987; 137:121-5.

8 Viscoli C, Van der Auwera P, Meunier F. Grampositive infections in granulocytopenic patients: an important issue? $\mathcal{F}$ Antimicrob Chemother 1988;21 (Suppl C): $149-56$.

9 Fleer A, Verhoef J. New aspects of staphylococcal infections: emergence of coagulase-negative staphylococci as pathogens. Antonie van Leeuwenhoek 1984;50: 729-44.

10 West TE, Walshe J, Krol CP, Amsterdam D. Staphylococcal peritonitis in patients on continuous peritoneal dialysis. $\mathcal{f}$ Clin Microbiol 1986;23:809-12.

11 Hovelius B. Epidemiological and clinical aspects of urinary tract infections caused by Staphylococcus saprophyticus. In: Mardh PA, Schleifer KH, eds. Coagulase negative In: Mardh PA, Schleifer $\mathrm{KH}$, eds. Coagulase negative
staphylococci. Stockholm: Almqvist and Wiksell staphylococci. Stockholm:

12 Lenkei G, Belicza É, Sztroj T, Rédai I, Rozgonyi F. Distribution and antibiotic resistance of coagulase-negative staphylococci isolated from human nosocomial infections. Proceedings of the 6th Mediterranean Congress of Chemotherapy. F Chemother 1989;(Suppl 4):277-9.

13 Gemmell CG, Schumacher-Perdreau F. Extracellular toxins and enzymes elaborated by coagulase-negative staphylococci. In: Mardh PA, Schleifer KH, eds. Coagulasenegative staphylococci. Stockholm: Almqvist and Wiksell negative staphylococci. Stockh

14 Solymossy M, Nagy Z, Antoni F. Cytotoxic material released from Staphylococcus epidermidis. I. Effects on ${ }^{3} \mathrm{H}$-thymidine incorporation of human lymphocytes. Acta Microbiol Acad Sci Hung 1982;29:27-32.

15 Solymossy M, Mandi J, Nagy Z, Antoni F. Cytotoxic material released from Staphylococcus epidermidis. II. Fractionation and some effects of the fractions on lymphocytes and hepatocytes. Acta Microbiol Acad Sci Hung 1982;29:277-84

16 Christensen GD, Simpson WA, Bisno AL, Beachey EH. Adherence of slime-producing strains of Staphylococcus Adherence of slime-producing strains of Staphylococcus epiderm

17 Rozgonyi F, Szitha KR, Ljungh A, Baloda SB, Hjertén S, Wadström $T$. Improvement of the salt aggregation test to study bacterial cell-surface hydrophobicity. FEMS Microbiol Lett 1985;30:131-8.

18 Beuth J, Ko HL, Schumacher-Perdreau F, Peters G, Heczko P, Pulverer G. Hemagglutination by Staphylococcus saprophyticus and other coagulase-negative staphylococci. Microbial Pathogenesis 1988;4:379-83.

19 Beuth J, Ko HL, Quie P, Pulverer G. Chemiluminescence response of human polymorphonuclear and mononuclear phagocytic cells induced by Staphylococcus nuclear phagocytic cells induced by Staphylococcus saprophyticus; lectinophagocyto
cytosis. Infection 1990;18:44-8.

20 Christensen GD, Simpson WA, Bisno AL, Beachey EH. Experimental foreign body infections in mice challenged with slime-producing Staphylococcus epidermidis. Infect Immun 1983;40:407-10.

21 Peters G, Gray ED, Johnson GM. Immunomodulating properties of extracellular slime substance. In: Bisno AL Waldvogel FA, eds. Infections associated with indwelling medical devices Washington, DC: American Society for Microbiology, 1989:61-74.

22 Wadström T, Rozgonyi F. Virulence determinants of coagulase-negative staphylococci. In: Mardh PA, Schleifer $\mathrm{KH}$, eds. Coagulase-negative staphylococci. Stock

23 Wadström T, Speziale P, Rozgonyi F, Ljungh A, Maxe I, Rydén C. Interactions of coagulase-negative staphylococci with fibronectin and collagen as a possible first step in tissue colonization in wounds and other tissue trauma. Zbl Bakt 1987;(Suppl 16):83-91.

24 Kloos WE, Schleifer KH. Simplified scheme for routine identification of human Staphylococcus species. $f$ Clin Microbiol 1975;1:82-8.

25 Akatov AK, Khatenever ML, Devriese LA. Identification of coagulase-negative staphylococci isolated from clinical of coagulase-negative staphylococci isolat

26 Bernheimer AW, Schwartz LL. Isolation and composition of staphylococcal alphatoxin. F Gen Microbiol 1963;30: of staph-63.

27 Gladstone GP, van Heyningen WE. Staphylococcal leukocidins. Br f Exp Pathol 1957;38:123-37.

28 Rozgonyi F, Kovács L, Váczi L. Genotypic stability of methicillin resistance in Staphylococcus aureus after persistence in mice. In: Mitsuhashi S, Krcméry V, Antal M, 
Rosival L, eds. Transferable antibiotic resistance: Plasmid and gene manipulation. Berlin:. Springer Verlag. 1984: 269-73

29 Holmberg O. Staphylococcus epidermidis isolated from bovine milk. Biochemical properties, phage sensitivity bovine milk. Biochemical properties, phage sensitivity 1973; (suppl 45):1-144

30 Ford CW, Hammel JC, Stapert D, Yancey RJ. Establishment of an experimental model of a Staphylococcus of dextran and gelatin microcarriers. f Med Microbiol 1989;28:259-66.

31 Ichiman $\mathrm{Y}$, Yoshida K. The relationship of capsular-type of Staphylococcus epidermidis to virulence and induction of resistance in the mouse. 7 Appl Bacteriol 1981;51:229-41.

32 Namavar F, de Graaff J, Verhoef J. Virulence of staphylococci (with special reference to experimental infection in neonatal mice, and the phagocytosis by polymorphoneonatal mice, and the phagocytosis by pol
nuclear cells). Zbl Bakt 1975;(suppl 5):813-8.
33 Baddour LM, Christensen GD, Hester MG, Bisno AL Production of experimental endocarditis by coagulasenegative staphylococci: Variability in species virulence. Infect Dis 1984;150:721-7.

34 Jonsson $P$, Kinsman $O$, Holmberg $O$, Wadström $T$. Virulence studies on coagulase-negative staphylococci in experimental infections: A preliminary report. Zbl Bakt 1981;(Suppl 10):661-6. A preliminary report. Zbl Bakt 1981;(Suppl 10):661-6.

35 Lambe DW, Ferguson KP, Keplinger JL, Gemmell CG, Kalbfleisch J. Pathogenicity of Staphylococcus lugdunensis, Staphylococcus schleiferi and three other coagulase-negative staphylococci in a mouse model. Can f Microbiol 1990;36:455-63.

36 Gray ED, Regelmann WE, Peters G. Staphylococcal slime and host defenses: Effects on lymphocytes and immune function. Zbl Bakt 1987;(suppl 16):45-54.

37 Drewry DT, Galbraith L, Wilkinson BJ, Wilkinson SG. Staphylococcal slime: a cautionary tale. $\mathcal{F}$ Clin Microbiol 1990;28:1292-6. 